\title{
AN ANALYTICAL MODEL ON STATIC SMOKE EXHAUST IN ATRIA
}

\author{
Cheuk Lun Chow ${ }^{1}$, Junmei $\mathbf{L i}^{2}$ \\ ${ }^{1}$ Department of Architecture, Wolfson College, University of Cambridg, UK \\ E-mail: nadiaclc@yahoo.com.hk (corresponding author) \\ ${ }^{2}$ The College of Architecture and Civil Engineering, Beijing University of Technology, Beijing, China \\ Received 19 Feb. 2010; accepted 07 May 2010
}

\begin{abstract}
Static smoke exhaust systems with natural vents are starting to be installed in big shopping complexes, warehouses and cargo terminals in the Far East. These systems are used for natural ventilation as well as for letting out smoke. This paper responds to concerns over the performance of static smoke exhaust systems, which remain less popular than dynamic smoke exhaust systems with mechanical fans. We propose a modification of a simple flow model found in the literature, adapting this to study smoke layer interface height with natural vents opened. We compare and justify our results, as generated by both Computational Fluid Dynamics and zone models, alongside reports of historical field tests. The model of smoke exhaust is applied in an illustrative example of a large hall, leading to the suggestion that a flow model could be used for designing natural vents. As the key driving force in removing smoke through natural vents is smoke's own buoyancy, the system might only be effective for bigger fires.
\end{abstract}

Keywords: smoke exhaust systems, natural vents, buoyancy, smoke layer interface height.

\section{Introduction}

Smoke management systems (Klote and Milke 1992; NFPA 2000) have to be installed to provide fire safety in large spaces. Burning even a small amount of modern synthetic materials generates a large quantity of smoke. Smoke exhaust systems are effective in keeping smoke above a certain level, thereby permitting fire fighting and the evacuation of blazing rooms. In East Asia, particularly Hong Kong, dynamic smoke exhaust systems with mechanical fans have been specified as the desired and sometimes mandatory means of clearing smoke from large halls (Fire Services Department 2005). Yet mechanical systems typically encounter serious difficulties in being able to supply a required exhaust rate of 8 air changes per hour in these spaces (Fire Services Department 2005). Further, it is difficult to allocate space within buildings' structure for installing fans and air ductworks. In consequence, many new projects are starting to put in alternatives such as static smoke exhaust systems. These natural vent devices include vertical vents inserted into side walls and horizontal ceiling vents; tall halls, such as atria located at the core of a building, will typically feature ceiling vents on account of the easier availability of roof space. A pressure difference is required for a vent to pass fluid from one side to the other-that is, from the area of high to the area of low pressure. This is the parameter in which it is feared that natural vents, despite their cost, space and energy advantages, would not work as well as mechanical fans.

The driving forces for natural ventilation (Klote and Milke 1992; NFPA 2000), which natural vents systems will have to harness, are stack effect, wind action and buoyancy. Wind-induced air motion (Poreh and Trebukov 2000) occurs dynamically, such that a well-designed natural venting system could function efficiently by exploiting windward and leeward pressure distributions. Especially in sultry climates, wind-induced pressure, though, might not be always available, and thus would not be reliable for letting out smoke in an emergency. Further, natural designs would have adverse effects in cases where wind blew into a hall with an adjacent tall building (Chow 2004). In places with a small difference between indoor and outdoor temperatures, stack pressure is also low, possibly being significant (Zhang et al. 2006) only in lift shafts or staircases with a large height to length ratio. In halls of a large cross-sectional area, there is some likelihood that stack pressure could be sufficiently high to open numerous air flow paths (for instance, in such open design as multi-storey shopping malls). Reverse stack pressure might also pull smoke down under some conditions.

The performance of static exhaust systems depends on factors affecting flow rates through ceiling vents, including the smoke layer temperature, smoke layer thickness, fire size and wind conditions. There is therefore a need to investigate smoke layer temperature and interface height under different fire sizes so as to explore the practicality of natural vents. The key driving force in smoke exhaust is buoyancy (Andersen 1995). If smoke is hot enough to be sufficiently buoyant, a static smoke extraction system may be able effectively to remove smoke from big halls. The bigger the fire size, the stronger smoke's buoyancy and hence the higher the exhaust rate (Andersen 1995; Klote 2000; Klote and Milke 1992; 
Li and Chow 2002-2003). Therefore, static smoke exhaust system might not work as expected for a small fire with low heat release rate. However, the damage in such small fires is not significant. In terms of the characteristics of exhaust systems' design, vent area, vent location and the time for which fires are allowed to burn are all important. It is not necessarily the case that larger-area vents will give a superior system performance under small fires. Equally, a vent designed for coping with big fires might see cool air pushing down, rather than hot gas moving up, if operated in the case of a small fire. The implication is that designs should feature a larger number of smaller-area vent to take advantage of smoke buoyancy. The literature reports numerous studies of vent flow induced by buoyancy (e.g. Andersen 1995; Cooper 2002; Klote 2000; Klote and Milke 1992; Li and Chow 20022003; Morgan and Gardner 1990; NFPA 1998, 2000). Li and Chow (2002-2003) review a number of these papers on calculating vent size by buoyancy. Reading this work offers a preliminary confirmation of the research that a flow model can be useful in evaluating the performance of natural vents.

In this paper, we will discuss a flow model approach to the design of a smoke exhaust system. The paper's proposed model will be put to use studying smoke exhaust from natural vents. Experimental results (Tanaka et al. 1987; Yamana and Tanaka 1985; Yang and Yeh 2005) available in the literature will be applied to justify model predictions, which will be generated by both Computational Fluid Dynamics (CFD) (McGrattan et al. 2008a, 2008b) and zone models (CFAST 2007). In our experimental simulations, smoke flows through a large hall as observed by the model (Chow 2006). The findings of these experiments are that natural vents may be efficient in extracting smoke from large atrium spaces if properly designed.

\section{Standard Buoyancy-Driven Flow Model}

Hot smoke generated by a building fire rises up to the ceiling on account of its own buoyancy. There are two layers in the building with an upper hot smoke layer and a lower cool air layer. Heat and mass will be transferred from the burning object at lower level to the upper hot smoke layer through the plume. The cross-sectional area of the building is assumed to be much larger than the areas of both the intake and exhaust openings. Physical properties of the upper smoke layer and the thickness would change with time. However, physical properties and thermal parameters such as air temperature of the layer are assumed to be uniform in space at any time. For purposes of fire management, it is important not to open ceiling vents immediately in case of fire, but only when the upper smoke layer is hot enough. Smoke can then be extracted effectively through the natural vent through taking advantage of its buoyancy as shown in Fig. 1a.

We can illustrate this by considering a hall of height $\mathrm{H}$ (in $\mathrm{m}$ ) with a smoke layer interface height $H_{g}$ (in $\mathrm{m}$ ). Taking the ambient air density as $\rho_{a}\left(\right.$ in $\mathrm{kgm}^{-3}$ ), the density of the hot gas as $\rho_{g}\left(\right.$ in $\left.\mathrm{kgm}^{-3}\right)$, the atmospheric pressure at the floor level as $\mathrm{P}_{0}$ (in $\mathrm{Pa}$ ), and the atmospheric pressure at the ceiling level as $\mathrm{P}_{00}$, the smoke exhaust flow can be visualized as a fluid blundle (e.g. Chow 2005; Li and Chow 2002-2003) moving between two points $\mathrm{A}$ and $\mathrm{C}$ at pressures $\mathrm{P}_{\mathrm{A}}$ and $\mathrm{P}_{\mathrm{C}}$ respectively, as in Fig. 1b. The pressure drop across the ceiling vent at $C$ is $\mathrm{P}_{\mathrm{C}}-\mathrm{P}_{00}$ and the pressure drop across the air inlet vent at $\mathrm{A}$ is $\mathrm{P}_{0}-\mathrm{P}_{\mathrm{A}}$.

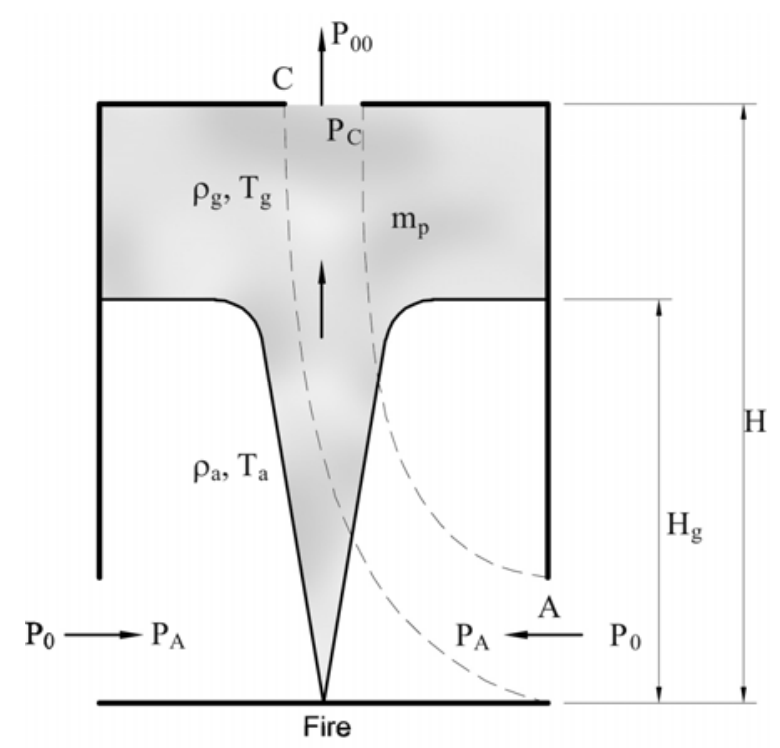

(a) Two-layer zone model under steady-state

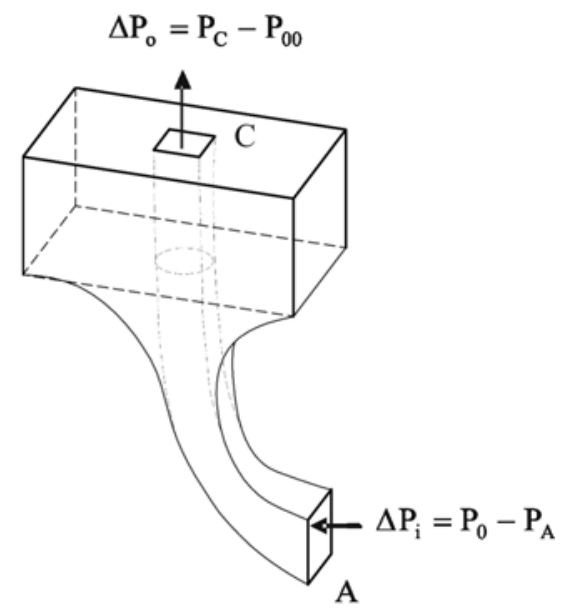

(b) A smoke bundle for deriving the key equation

Fig. 1. Ceiling vent

The pressure drop $\Delta P_{o}$ (in $\mathrm{Pa}$ ) across the ceiling vent caused by the difference in densities of the smoke layer and the surrounding cold air as shown in Fig. 1 can be given as:

$$
\Delta P_{o}=P_{C}-P_{00}=\left(P_{A}-P_{0}\right)+\left(\rho_{a}-\rho_{g}\right) g\left(H-H_{g}\right) .
$$

This can be expressed as the pressure drop across the inlet vent $\Delta P_{\mathrm{i}}$ (in $\mathrm{Pa}$ ) as:

$$
\Delta P_{o}=\rho_{a} g^{\prime}\left(H-H_{g}\right)-\Delta P_{i}
$$

The reduced gravity due to buoyancy g' (in $\mathrm{ms}^{-2}$ ) is defined by: 


$$
g^{\prime}=\frac{\Delta \rho}{\rho_{a}} g .
$$

$\Delta P_{o}$ can be further simplified in terms of the pressure difference due to buoyancy or $\Delta P_{F}$ as:

$$
\Delta P_{o}=\Delta P_{F}-\Delta P_{i}
$$

where

$$
\Delta P_{F}=\rho_{a} g^{\prime}\left(H-H_{g}\right) .
$$

Applying Bernoulli's theorem on the fluid bundle shown in Fig. 1b, the velocity across the ceiling vent $v_{0}$ (in $\mathrm{ms}^{-1}$ ) can be calculated by:

$$
v_{o}=\left[\frac{2 g\left(\rho_{a}-\rho_{g}\right)\left(H-H_{g}\right)}{\left(1+\frac{\rho_{g} C_{o}^{2} A_{o}^{2}}{\rho_{a} C_{i}^{2} A_{i}^{2}}\right) \rho_{g}}\right]^{1 / 2} .
$$

In the above equation, $C_{i}$ and $C_{0}$ are the discharge coefficients of the inlet and outlet vents respectively, and $A_{i}$ and $A_{0}$ the areas of the inlet and outlet opening respectively. Detailed derivations of the vent flow velocity are presented in the paper by Li and Chow (2002-2003).

Applying the ideal gas law gives the relation between $\rho_{g}$ and temperature $T_{g}$ (in K) of the hot gas layer, density $\rho_{a}$ and temperature $T_{a}$ of ambient air:

$$
\rho_{g} T_{g}=\rho_{a} T_{a} .
$$

Equation (5) can be rewritten as:

$$
v_{o}=\left[\frac{2 g\left(T_{g}-T_{a}\right)\left(H-H_{g}\right)}{\left(1+\frac{T_{a} C_{o}^{2} A_{o}^{2}}{T_{g} C_{i}^{2} A_{i}^{2}}\right) T_{a}}\right]^{1 / 2} .
$$

The mass flow rate across the ceiling vent $\mathrm{m}_{\mathrm{e}}\left(\mathrm{in} \mathrm{kgs}^{-1}\right.$ ) may then be calculated by:

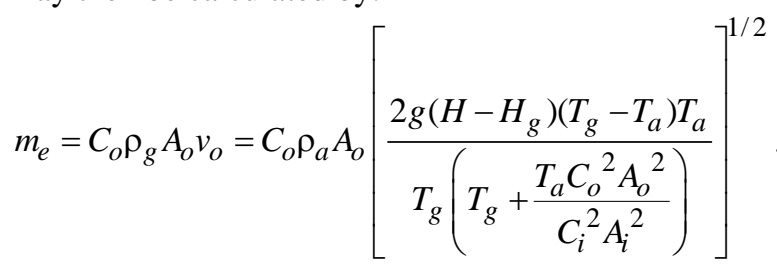

It is generally considered a requirement of a good design that the total surface area of the inlet vents is relatively larger than the area of the exhaust. In this way, adequate make-up air can be supplied. In practice, there are many openings at the lower levels and so area of inlet vents is higher, except some poorly designed examples. This would mean that the pressure drop across the inlet vents would be negligible in comparison with the pressure drop $\Delta P_{o}$ across the open ceiling vents (Cooper 2002). The minimum stipulation for a design's vent area is defined as the least area meeting fire safety criteria for a given building (NFPA 1998). This is often derived by buil- ding the design of smoke management systems around an assumption of steady-state vent flow.

To satisfy the design objective of keeping the smoke layer at height $H_{g}$, the mass flow rate out of the vents $m_{e}$ should be of a value similar to the mass production rate of smoke $m_{p}\left(\right.$ in $\left.\mathrm{kgs}^{-1}\right)$ at the interface height:

$$
m_{e}=m_{p} .
$$

The required vent area to keep smoke at this interface height $H_{g}$ can be calculated by:

$$
C_{o} A_{o}=m_{p} / \rho_{a}\left[\frac{2 g\left(H-H_{g}\right)\left(T_{g}-T_{a}\right) T_{a}}{T_{g}\left(T_{g}+\frac{T_{a} C_{o}^{2} A_{o}^{2}}{C_{i}^{2} A_{i}^{2}}\right)}\right]^{-1 / 2} .
$$

Ignoring heat loss through the atrium, energy conservation of the upper hot gas layer gives $T_{g}$ in terms of the convective heat release rate of the fire $\mathrm{Q}_{c}$ (in $\mathrm{W}$ ):

$$
\frac{T_{g}}{T_{a}}=\frac{Q_{c}}{m_{p} C_{p} T_{a}}+1
$$

Substituting the above equation into equation (9), we get:

$$
C_{o} A_{b}=\frac{m_{p}}{\rho_{a}}\left\{\frac{\left(\frac{Q_{C}}{m_{p} C_{p} T_{a}}+1\right)\left[\left(\frac{Q_{C}}{m_{p} C_{p} T_{a}}+1\right)+\frac{C_{o}^{2} A_{b}^{2}}{C_{i}^{2} A_{i}^{2}}\right]}{2 g\left(H-H_{g}\right) \frac{Q_{C}}{m_{p} C_{p} T_{a}}}\right\}^{1 / 2} .
$$

Assuming $A_{i} \gg A_{o}$, the required ventilation area can then be calculated by:

$$
\begin{gathered}
C_{o} A_{o}=\frac{m_{p}\left(\frac{Q_{c}}{m_{p} C_{p} T_{a}}+1\right)}{\rho_{a}\left[2 g\left(H-H_{g}\right) \frac{Q_{C}}{m_{p} C_{p} T_{a}}\right]^{1 / 2}}= \\
\frac{F^{1 / 2}\left(m_{p}{ }^{1 / 2}+\frac{m_{p}{ }^{3 / 2} C_{p} T_{a}}{Q_{c}}\right)}{g\left[2 \rho_{a}\left(H-H_{g}\right)\right]^{1 / 2}},
\end{gathered}
$$

where $F$ is the buoyancy flux of the hot smoke defined (Li and Chow 2002-2003; Hu et al. 2004) by:

$$
F=\frac{g Q_{c}}{\rho_{a} C_{p} T_{a}} .
$$

The mass flow rate of the plume $\mathrm{m}_{\mathrm{p}}$ (in $\mathrm{kgs}^{-1}$ ) depends on the location of the fire in the hall. For a fire at the floor level, axisymmetric plume equations such as Heskestad's (1984) can be used to calculate the required vent area. Axisymmetric plume equation due to Heskestad is:

$$
m_{p}=0.071 Q_{C}^{1 / 3} z^{5 / 3}+0.0018 Q_{C} .
$$

Substituting the above plume equation in equation (12) gives: 


$$
C_{o} A_{o}=\frac{F^{1 / 2}\left[0.266 Q_{c}^{1 / 6}\left(H_{g}^{5 / 3}+0.0254 Q_{c}^{2 / 3}\right)^{1 / 2}+0.0189 Q_{c}^{-1 / 2} C_{p} T_{a}\left(H_{g}^{5 / 3}+0.0254 Q_{c}^{2 / 3}\right)^{3 / 2}\right]}{g\left[2 \rho_{a}\left(H-H_{g}\right)\right]^{1 / 2}} .
$$

\section{Effect of Smoke Layer Temperature}

Defining $\phi$ as the ratio of $T_{g}$ to $T_{a}$ for a ceiling vent with area $\mathrm{A}_{0}$ in an atrium with smoke interface height $H_{g}$ :

$$
\phi=\frac{T_{g}}{T_{a}} .
$$

If we then rewrite the vent flow equation (7) as:

$$
m_{e}=C_{o} \rho_{a} A_{o}\left[\frac{2 g\left(H-H_{g}\right)(\phi-1)}{\phi\left(\phi+\frac{C_{o}^{2} A_{o}^{2}}{C_{i}^{2} A_{i}^{2}}\right)}\right]^{1 / 2},
$$

the effect of smoke temperature on ventilation capacity is shown in Fig. 2. The vent flow rate need not always increase proportionately with the smoke layer temperature

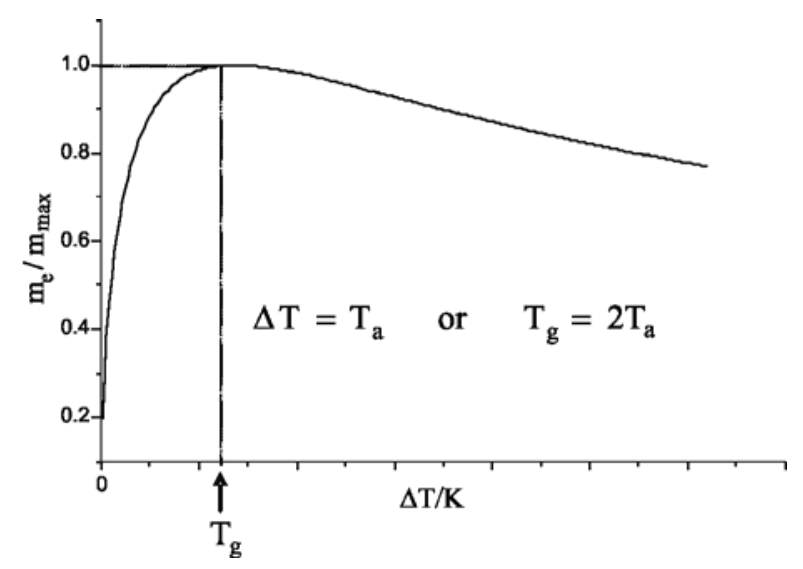

Fig. 2. Effects of smoke temperature on the extraction mass flow rate through the vent

for the smoke layer thickness to remain at a fixed value. Rather, a maximum value of $m_{e}$ denoted by $m_{\max }$ is reached at a certain smoke layer temperature. A vent flow rate greater than $m_{\max }$ will then fall as the gas temperature goes up. The value of $m_{\max }$ can be derived by taking:

$$
\frac{d m_{e}}{d \phi}=0
$$

giving:

$$
\phi=1+\left(\frac{C_{o}^{2} A_{o}^{2}}{C_{i}^{2} A_{i}^{2}}+1\right)^{1 / 2}
$$

Detailed derivation of equation (19) can be found in Appendix A. Assuming the large inlet area, $A_{i}>>A_{o}$,

$$
\phi \approx 2
$$

therefore, $T_{g}$ will be given by:

$$
T_{g} \approx 2 \mathrm{~T}_{a}
$$

or

$$
\Delta T=T_{g}-\mathrm{T}_{a} \approx \mathrm{T}_{a} .
$$

Under this condition of $T_{g}=2 T_{a}$ or $\Delta T=T_{a}$, the vent flow rate tops out at the maximum value $m_{\max }$.

\section{Effects of Heat Release Rate on Smoke Layer Interface Height}

The heat release rate of fire being modeled is a key factor in the design of smoke management systems. This creates design difficulties in that change of atrium uses would lead to fires of a different release rate. This rate depends not only on the fire load, but also on the types of combustibles found in the indoor environment and consumed in the fire. This in turn leads to variation, and this to deviation from design predictions, in the smoke layer interface height satisfying the mass balancing of the exhaust rate and the plume entrainment rate. In these instances, we need to keep the interface height at a higher value than the minimum that would facilitate a safe evacuation. There is an obvious need to study relations between interface height and fire size in designing natural vents.

We can begin by defining a parameter $A$ as:

$$
A=C_{o} A_{o} g\left(2 \rho_{a} H\right)^{1 / 2} .
$$

As shown before, the vent flow equation is:

$$
m_{e}=A\left[(1-\xi) \frac{\rho_{a}}{g}\left(\frac{T_{g}}{T_{a}}-1\right)\right]^{1 / 2}\left(\frac{T_{g}}{T_{a}}\right)^{-1},
$$

where $\xi$ is the smoke layer interface height expressed as a ratio of the ceiling height $\mathrm{H}$ :

$$
\xi=H_{g} / H \text {. }
$$

Combining this with equation (10) and using mass conservation to take $\mathrm{m}_{\mathrm{p}}$ as $\mathrm{m}_{\mathrm{e}}$, supposing equation (12) on $\mathrm{F}, \xi$ can be calculated by:

$$
\xi=1-\frac{F m_{p}}{A^{2}}\left[1+\frac{m_{p} C_{p} T_{a}}{Q_{C}}\right]^{2}
$$

Substituting Heskestad's axisymmetric plume equation (Heskestad 1984),

$$
\begin{aligned}
\xi= & 1-\frac{F}{Q_{C} A^{2}}\left[Q_{C}{ }^{2 / 3}\left(0.071 H^{5 / 3} \xi^{5 / 3}+0.0018 Q_{C}^{2 / 3}\right)^{1 / 2}+\right. \\
& \left.\left(0.071 H^{5 / 3} \xi^{5 / 3}+0.0018 Q_{C}^{2 / 3}\right)^{3 / 2} C_{p} T_{a}\right]^{2} .
\end{aligned}
$$

As $A_{i}$ might not be larger than $A_{o}$ for some projects, a more general equation on the smoke layer height is presented as: 


$$
\begin{aligned}
& \xi=1-\frac{\left(0.071 Q_{C}^{1 / 3} \xi^{5 / 3}+0.0018 Q_{C} H^{-5 / 3}\right)^{2} H^{7 / 3}}{2 g C_{o}^{2} A_{o}^{2} \rho_{a}^{2}} . \\
& {\left[\left(1+\left(0.071 Q_{C}^{-2 / 3} \xi^{5 / 3}+0.0018 H^{-5 / 3}\right) C_{p} T_{a} H^{5 / 3}\right] .\right.} \\
& {\left[\frac{1}{\left(0.071 Q_{C}^{-2 / 3} \xi^{5 / 3}+0.0018 H^{-5 / 3}\right) C_{p} T_{a} H^{5 / 3}}+\right.} \\
& \left.1+\frac{C_{o}^{2} A_{o}^{2}}{C_{i}^{2} A_{i}^{2}}\right]
\end{aligned}
$$

Solving the above equation numerically yields smoke layer interface heights under different fire sizes. Detailed derivations of equations (27) and (28) are shown in Appendix B.

\section{Field Tests at Japan}

The flow model on static smoke exhaust system given by equation (28) can be justified by tests reported in the literature. Good-quality data has been reported from field tests carried out at the SR hall (Tanaka and Yamana 1987) for Scientific and Technology Exhibitions in Japan. The hall is of length $21.3 \mathrm{~m}$, width $21.3 \mathrm{~m}$ and height $9.9 \mathrm{~m}$ and had a $2.5 \mathrm{~m}^{2}$ pool fire set up in positions described in Fig. 3. The heat release rate per unit area of the pool fire was estimated from an earlier study on an experimental hall to come in at $0.4 \mathrm{MWm}^{-2}$, for a total heat release of about $1 \mathrm{MW}$.

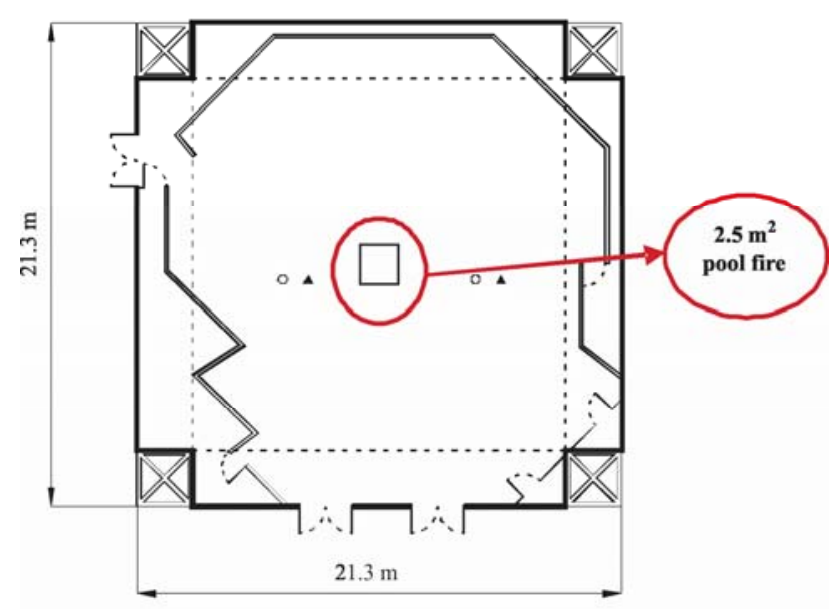

(a) Plan

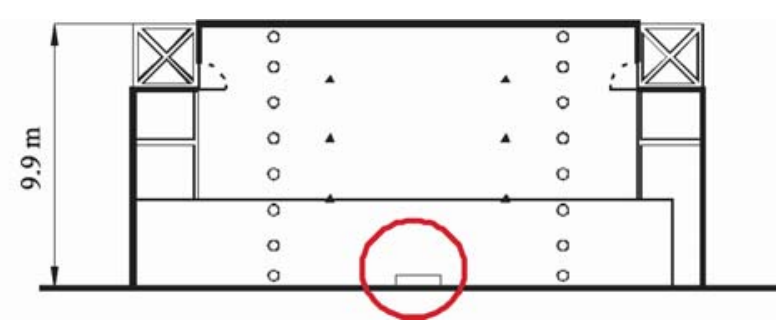

(b) Elevation

Fig. 3. The SR hall
Five tests were carried out in the SR hall relevant to this study:

- SR01: Natural smoke filling with 1 air inlet opening of area $2.47 \mathrm{~m}^{2}$.

- SR02: Natural smoke filling with 4 natural smoke exhaust vents of a total area $11.5 \mathrm{~m}^{2}$; 1 air inlet opening of area $2.47 \mathrm{~m}^{2}$.

- SR03: Natural smoke filling with 4 natural smoke exhaust vents of a total area $11.5 \mathrm{~m}^{2}$; 4 air inlet openings of total area $9.98 \mathrm{~m}^{2}$.

- SR04: Natural smoke filling with 2 natural smoke exhaust vents of a total area $5.76 \mathrm{~m}^{2} ; 4$ air inlet openings of total area $9.98 \mathrm{~m}^{2}$.

- SR05: Natural smoke filling with 4 natural smoke exhaust vents of a total area $5.76 \mathrm{~m}^{2}$; 4 air inlet openings of total area $9.98 \mathrm{~m}^{2}$.

Results for transient smoke layers are shown in Fig. 4. In test SR01 and SR02 with natural smoke filling, smoke fell to the ground, not being held at an interface or evacuation height; the air inlet vent area was thus inadequate. However, tests SR03, SR04 and SR05 suggest that well-designed inlet vents would have led to smoke layers falling down slowly and being kept at an interface height above $2.4 \mathrm{~m}$. This would seem once again to imply that an appropriately-designed natural vent can be effective in keeping the smoke layer above a certain height.

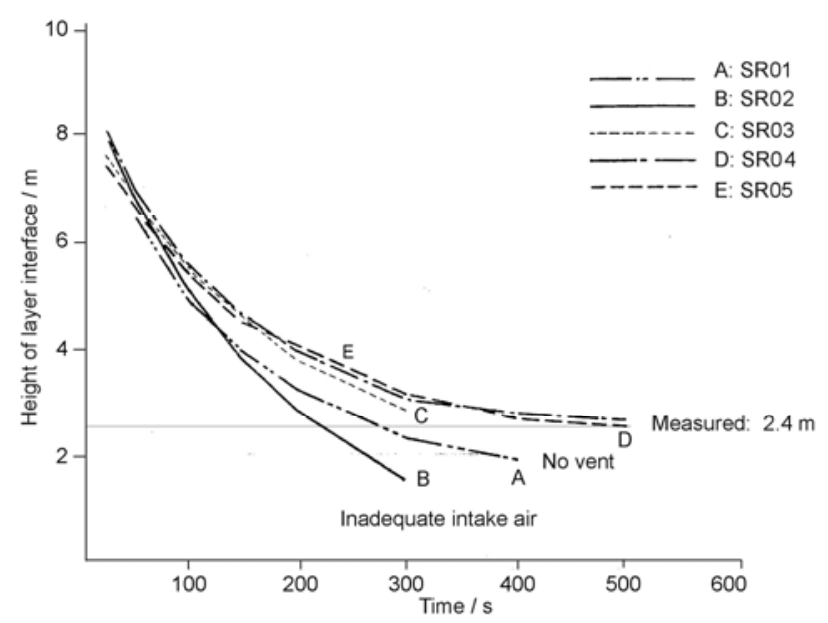

Fig. 4. Smoke layer interface heights at the SR hall

The smoke layer interface heights for cases SR02, SR03 and SR04 were calculated using the flow model given by equation (28) as shown in Table 1 . The results predicted by the flow model suggested that designing a venting system with the wrong air intake rate would not fail to keep the smoke layer at a safely high level. This is similar to the field tests' observations. However, the results as they concern smoke layer interface heights at the final stage of burning differ to some degree from those of tests. As the heat release rate was not clearly stated, its value might come in at over $1 \mathrm{MW}$, going up to $3 \mathrm{MW}$, based on data reported earlier (Tanaka et al. 1987; Yamana and Tanaka 1985). 
Table 1. Comparison of the smoke layer heights predicted by different methods

\begin{tabular}{l|c|c|c|c}
\hline \multirow{2}{*}{$\begin{array}{c}\text { Japan SR } \\
\text { hall }\end{array}$} & \multicolumn{4}{|c}{$\mathrm{H}_{\mathrm{g}} / \mathrm{m}$} \\
\cline { 2 - 5 } & Field test & Flow model & FDS & CFAST \\
\hline SR01 & $<2$ & & 1.2 & 0.3 \\
\hline SR02 & 1.8 & 3.6 & 1.4 & 4.0 \\
\hline SR03 & $>2.4$ & 6.8 & 5.6 & 5.8 \\
\hline SR04/SR05 & 2.4 & 5.8 & 5.3 & 5.1 \\
\hline
\end{tabular}

\section{Field Tests in a Railway Terminal Building in Taiwan}

Another set of data on smoke filling and exhaust has been recently reported, describing the performance of a static exhaust system dealing with a hot smoke test in the hall of a railway terminal in Taiwan (Yang and Yeh 2006). The building is of ceiling height between 20 to $25 \mathrm{~m}$ as shown in Fig. 5. Natural vent areas were designed to have a surface area of $379 \mathrm{~m}^{2}$. The fire in field tests of this static exhaust system was a fast $\mathrm{t}^{2}$-fire with a cut-off value of $5 \mathrm{MW}$. A total of 25 gasoline pans of $0.45 \mathrm{~m}$ diameter were burnt, with each pan giving off about $0.2 \mathrm{MW}$.

Fig. 6 shows results for the smoke layer interface height with smoke dispersing through a natural vent. The vent successfully kept the smoke layer at a height above $17 \mathrm{~m}$, about $68 \%$ of the maximum ceiling height, again demonstrating natural systems' efficacy in allowing smoke to dissipate.

Our flow model, meanwhile, estimated the smoke layer interface at a height of $19.7 \mathrm{~m}$ by equation (28). This is very similar to the value measured by observation and can be counted as a good agreement, bearing in mind the simplicity of our equation and the irregular shape of the large hall.

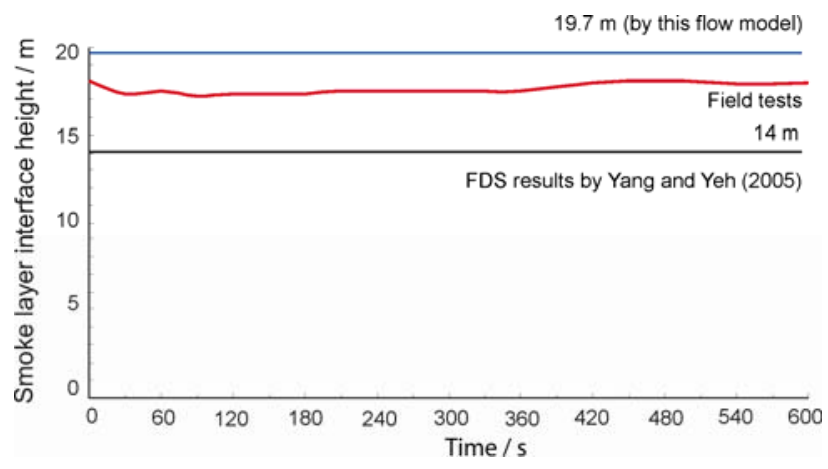

Fig. 6. Smoke layer interface heights at a Taiwan railway hall (Yang and Yeh 2005)

\section{Fire Model Simulations}

Smoke exhaust systems' performance may also be evaluated by CFD. The CFD software Fire Dynamics Simulator (FDS), developed at the Building and Fire Research Laboratory at the US National Institute of Standards and Technology may be used (McGrattan et al. 2008a, 2008b) as a further justification of the flow model given by equation (27). We can also cross-compare the estimations of the FDS simulator, the flow equation and observations in order to get some sense of the validity of the simulated methods. The input heat release rate $\mathrm{Q}_{c}$ curve for fire simulation is shown in Fig. 7. The walls and ceiling are taken to be adiabatic. Sensitivity of the grid system was studied and the optimum grid system is determined to be $108 \times 108 \times 50$ for simulating all SR cases.

Further, smoke layer interface heights in the SR hall have also been predicted by the zone model CFAST (2007). Results are compared with empirical equations, experiments and FDS simulations in Fig. 8. Table 1 presents a summary of the predicted smoke layer interface heights at the steady burning stage of the pool fire for different tests. The table shows that measured values in the SR Hall across the five tests SR01 to SR05 differ from the predictions of the flow model, FDS and CFAST. However, the predicted results of the flow model agree well with CFAST, as both assume a two-layer picture.

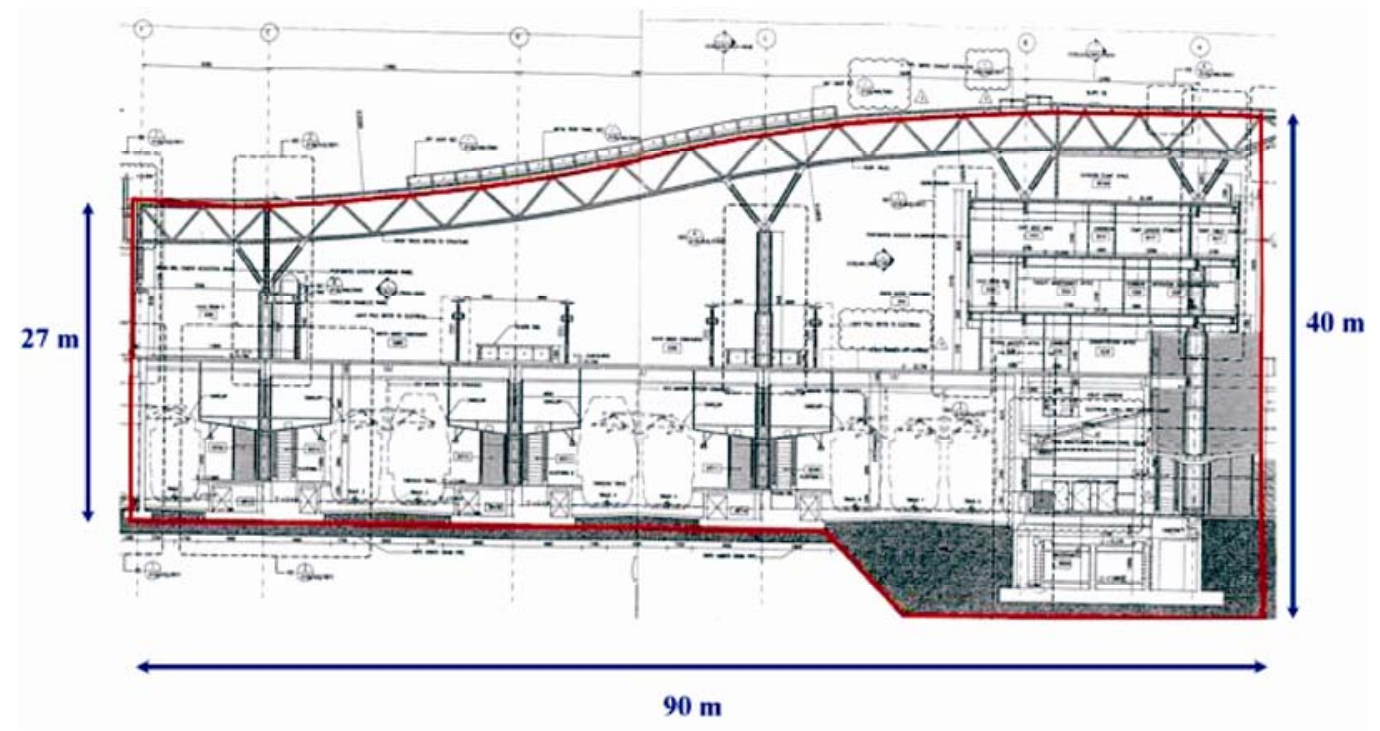

Fig. 5. The railway hall in Taiwan (Yang and Yeh 2005) 


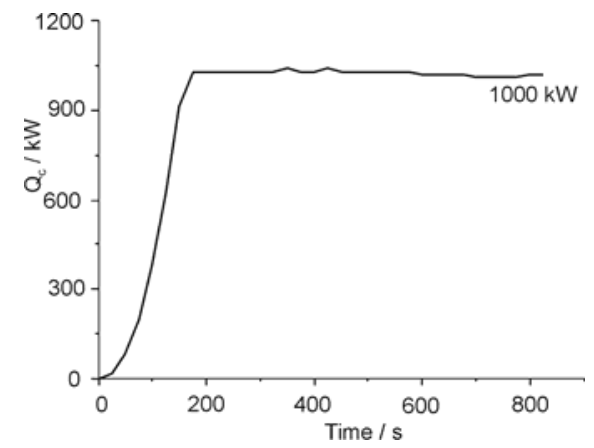

Fig. 7. Heat release rate curve for the SR hall

Table 1 again shows the predictions of the flow model, CFAST and FDS. The predicted smoke layer interface heights were lower for higher heat release rates, agreed better with experiments.

Smoke layer interface height at the Taiwan Railway Terminal was predicted by FDS at $14 \mathrm{~m}$ as shown in Fig. 6, very close to the predictions of both simple flow model and CFAST.

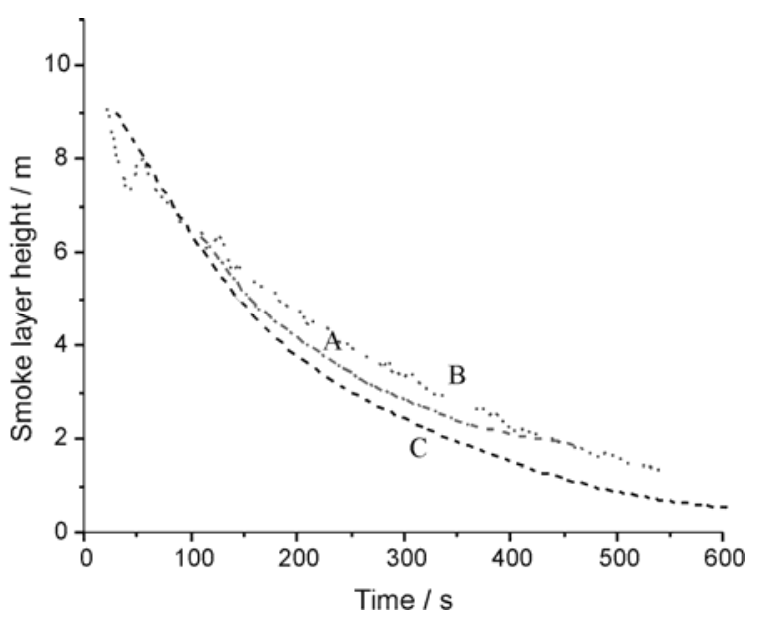

(a) SR01

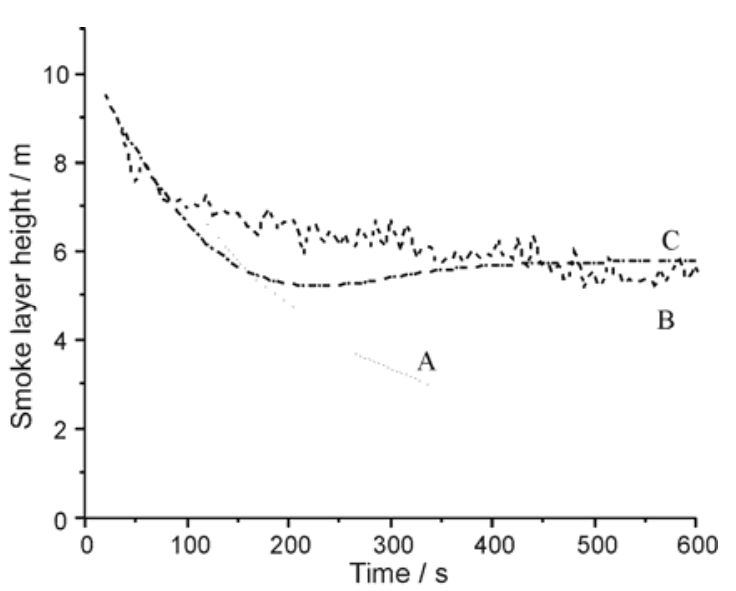

(c) SR03
As illustrated by Fig. 8, showing transient smoke layer interface predictions, all real and projected data agreed reasonably well at an early stage. However, results at later stages of burning deviated, as the smoke layer interface height is not easy to determine experimentally during the later stages of a fire. It is easy to suppose in such instances that temperature profiles and visual observation, which are likely to be obscured, will give different results. Test fires in field tests are thus vulnerable to special problems when it comes to evaluating the performance of smoke exhaust systems coping with smoke generated in atria. Different smoke generation methods have been studied in detail on large halls and tunnels in Taiwan (Yang and Chow 2008) over the past ten years. Some commentators have concluded that white smoke generated from smoke guns would give a clearer position of the height of the smoke layer interface. Further, this would provide a clean environment (Yang and Chow 2008) after carrying out tests with black smoke while burning gasoline. However, the smoke would not necessarily be of the required temperature and buoyancy.

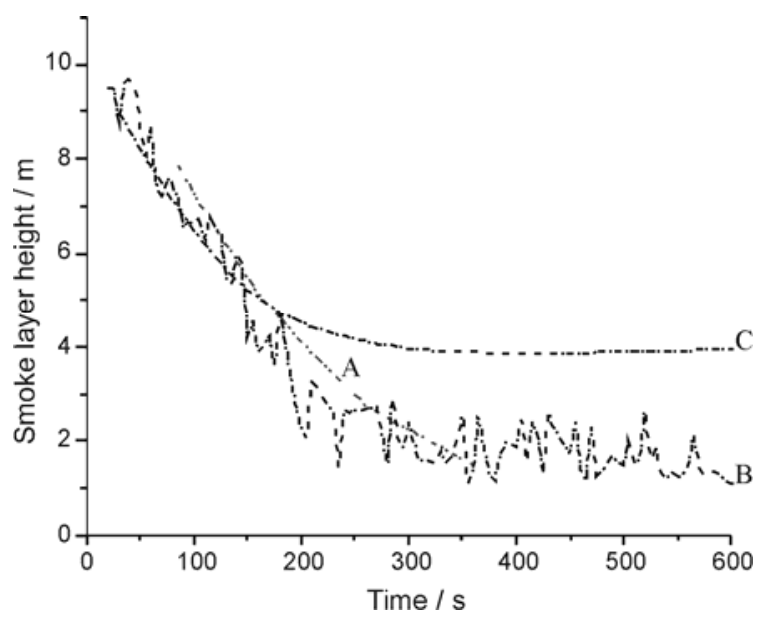

(b) SR02

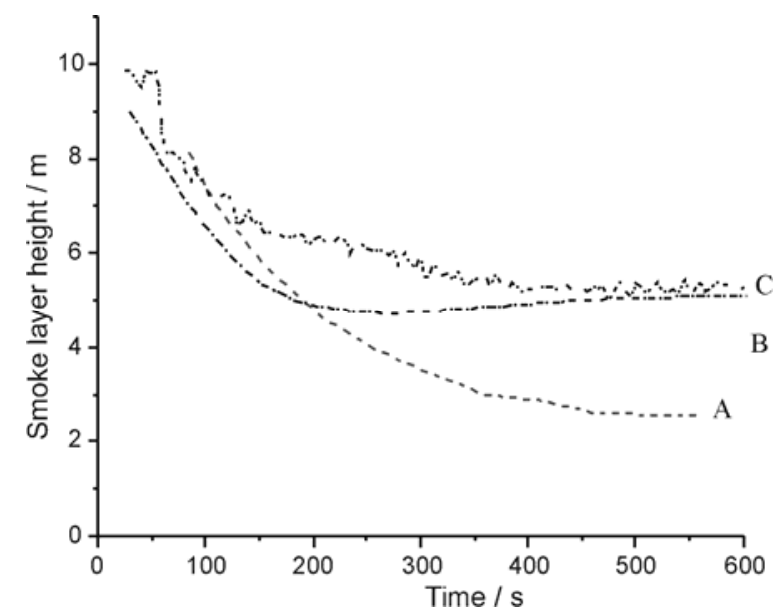

(d) $\mathrm{SR} 04$

A: Measured results B: FDS results C: CFAST results

Fig. 8. Comparison of smoke layer interface heights with a $1 \mathrm{MW}$ fire 
Variation of the interface height $\xi$ and smoke vent flow rate with the convective heat release rate $Q_{c}$ for case SR04 are shown in Figs. 9 and 10 with the ambient temperature taken to be $20^{\circ} \mathrm{C}$. For this smoke vent system, smoke layer interface would decrease, but mass vent flow rate would increase while increasing the fire size.

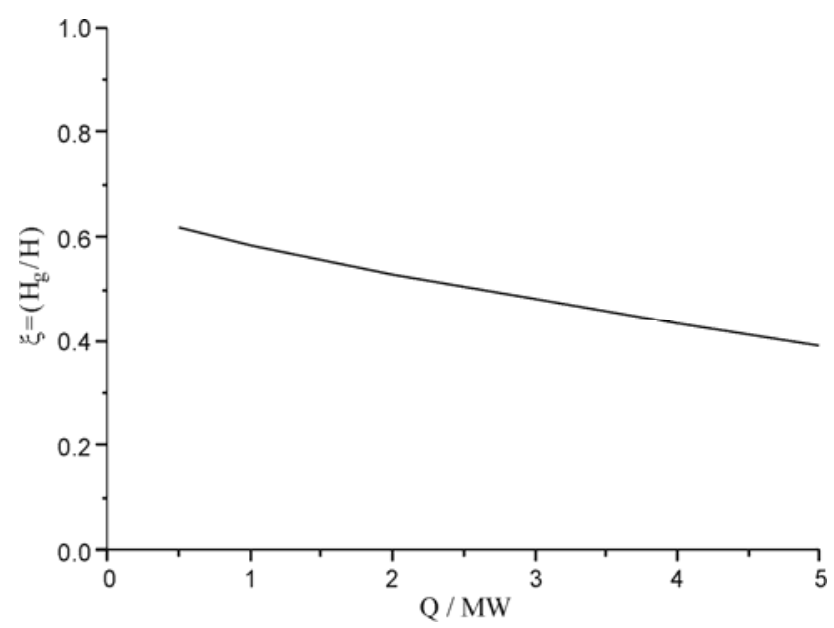

Fig. 9. Effects of fire size on the vent flow for Case SR04

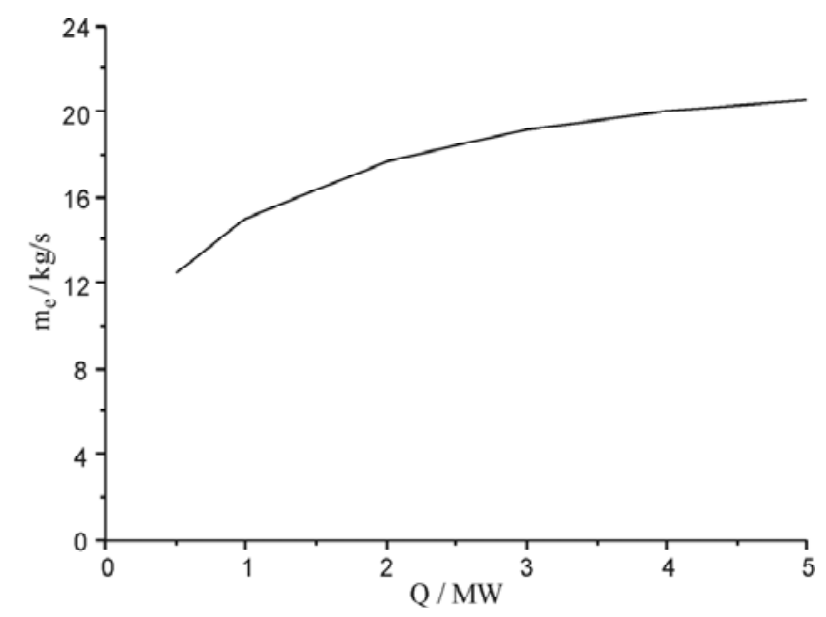

Fig. 10. Variation of the mass exhaust rate with the fire size for SR04

\section{Conclusion}

This paper modified a simple buoyancy-driven flow model to determine the smoke layer interface heights for a static smoke exhaust system. The development of such a model can be useful in preliminary hazard assessment of many scenarios with big halls where static exhaust systems will be preferable for space and environmental reasons. Our model flow predicts that smoke layer interface heights will flow out of natural vents more quickly the hotter the smoke. Maximum exhaust rates will be achieved when the temperature of the smoke layer comes in at twice the ambient value. Note that a zone model does not include initial lateral flow of smoke across the ceiling. Results predicted by this model should be justified for spaces with large ceiling areas of irregular shape and rough ceiling. As proposed by Cooper (1993, 1995), the approach would not work very well for the cases with very low pressure drop across the vent.

This study referred for the purposes of validating its model to actual field tests of static smoke exhaust systems in big halls carried out in Japan and Taiwan. Data from all these sources bore out the suggestion that appropriately-designed natural vents can be effective in removing smoke, even in small fires. All five tests at the Japanese SR Hall indicated that a good design of static smoke exhaust system with an adequate inlet vent area can maintain a smoke layer at a safe height. The test in a hall in Taiwan suggested that an appropriate design of the static smoke exhaust system can keep the smoke layer as far up as $70 \%$ of the ceiling height above ground level. The flow model's results for smoke layer interface height agreed well with the Taiwanese test, though less well with the Japanese test. A possible explanation can be found in terms of different criteria for determining the smoke layer interface, especially insofar as visual observations in this parameter in the latter stages of hot smoke fires may be inaccurate. The Taiwanese data may be considered the more reliable in examining smoke generation in great detail for the purposes of evaluating smoke exhaust systems (Yang and Chow 2008). Further, the simulation predictions of FDS, CFAST and the proposed flow model results agreed well with each other. These tests concurred with the central finding that a natural vent is effective in keeping smoke above a certain height.

\section{Acknowledgement}

We would like to thank Professor W. K. Chow for his advice on this work.

\section{References}

Andersen, K. T. 1995. Theoretical considerations on natural ventilation by thermal buoyancy, ASHRAE Transactions 101(2): 1103-1117.

CFAST, 2007. Consolidated Model of Fire Growth and Smoke Transport. Available from Internet: <http://www.bfrl.nist.gov/866/fmabbs.html\#CFAST>.

Chow, W. K. 2004. Wind-induced indoor-air flow in a high-rise building adjacent to a vertical wall, Applied Energy 77(2): 225-234. doi:10.1016/S0306-2619(03)00121-1

Chow, W. K. 2005. Atrium smoke exhaust and technical issues on hot smoke tests, in ASME 2005 Summer Heat Transfer Conference, July 17-22, 2005, Westin St. Francis, San Francisco, CA, USA. 4 p.

Chow, W. K. 2006. Computational fluid dynamics simulation on wind induced air flow on ceiling vent, in $12^{\text {th }}$ China Higher Education Engineering Thermophysics Conference, Chongqing, China, May 2006.

Cooper, L. Y. 1993. Combined buoyancy-and pressure-driven flow through a horizontal vent: theoretical considerations, NISTIR 5252, National Institute of Standards and Technology, Gaithersburg, MD, USA.

Cooper, L. Y. 1995. Combined buoyancy and pressure-driven flow through a shallow, horizontal, circular vent, Journal of Heat Transfer 117: 659-667. doi:10.1115/1.2822627

Cooper, L. Y. 2002. Smoke and heat venting, in P. J. Dinenno (Ed.). The SFPE Handbook of Fire Protection Enginee- 
ring, $3^{\text {rd }}$ ed. National Fire Protection Association, Quincy, Massachusetts, USA, 3-219-3-242.

Fire Services Department, 2005. Codes of Practice for Minimum Fire Service Installations and Equipment and Inspection, Testing and Maintenance of Installations and Equipment. Fire Services Department, Hong Kong, 120 p.

Heskestad, G. 1984. Engineering relations for fire plumes, Fire Safety Journal 7: 25-32. doi:10.1016/0379-7112(84)90005-5

Hu, L. H.; Li, Y. Z.; Huo, R.; Yi, L.; Shi, C. L.; Chow, W. K. 2004. Experimental studies on the rise-time of buoyant fire plume fronts induced by pool fires, Journal of Fire Sciences 22: 69-86. doi:10.1177/0734904104039696

Klote, J. H. 2000. New development in atrium smoke management, ASHARE Transactions 106(I): 620-626.

Klote, J. H.; Milke, J. A. 1992. Design of smoke management systems, American Society of Heating, Refrigerating and Air Conditioning Engineers, Inc., Atlanta, Ga., USA; Society of Fire Protection Engineers, Boston, MA, USA.

Li, J.; Chow, W. K. 2002-2003. On designing horizontal ceiling vent in an atrium, Journal of Applied Fire Science 11(3): 229-254. doi:10.2190/RK04-K8TA-1J92-E0F0

McGrattan, K.; Klein, B.; Hostikka, S.; Floyd, J. 2008a. Fire Dynamics Simulator (Version 5) User's Guide, NIST Special Publication 1019-5, National Institute of Standards and Technology, US Department of Commerce, USA, January 2008.

McGrattan, K.; Hostikka, S.; Floyd, J.; Baum, H.; Rehm, R.; Mell, W.; McDermott, R. 2008b. Fire Dynamics Simulator (Version 5) - Technical Reference Guide, NIST Special Publication 1018-5, National Institute of Standards and Technology, US Department of Commerce, USA, October 2008.

Morgan, H. P.; Gardner, J. P. 1990. Design principles for smoke ventilation in enclosed shopping centers, Building Research Establishment Report, CI/SIB 34(K3), Building Research Establishment, Garston, UK.

NFPA, 1998. NFPA 204M, Guide for smoke and heat venting. National Fire Protection Association, Quincy, MA, USA.

NFPA, 2000. NFPA 92B Guide for Smoke Management Systems in Malls, Atria, and Large Areas, National Fire Protection Association, Quincy, MA, USA.

Poreh, M.; Trebukov, S. 2000. Wind effects on smoke motion in buildings, Fire Safety Journal 35: 257-273. doi:10.1016/S0379-7112(00)00017-5

Tanaka, T.; Yamana, T.; Nakamura, I. 1987, Full scale smoke exhaust experiments at the Pavilions of Science and Technology Exposition, Study of Disasters 18: 142-155.

Yamana, T.; Tanaka, T. 1985. Smoke control in large scale spaces, Part 2: Smoke control experiments in large scale spaces, Fire Science and Technology 5(1): 41-54.

Yang, K. H.; Chow, W. K. 2008. Open Forum on Full-scale Burning Tests in Tunnel. Railway Reform Bureau. Taipei, Taiwan, 28 November 2008.

Yang, K. H.; Yeh, T. C. 2005. Design analysis and experimental investigation of the smoke management system performances of an HSR station, International Journal on Architectural Science 6(3): 106-113.

Zhang, J. Y.; Ji, J.; Huo, R.; Yuan, H. Y.; Yang, R. 2006. A comparison of simulation and experiment on stack effect in long vertical shaft, Journal of Fire Sciences 24(2): 121-135. doi:10.1177/0734904106055573

\section{Appendix A: Derivation of equation (19)}

The mass flow rate across the ceiling vent $m_{e}$ is given in terms of the ratio $\phi$ of the absolute temperature of the hot smoke layer $T_{g}$ to the temperature of the ambient air $T_{a}$ :

$$
m_{e}=C_{o} \rho_{a} A_{o}\left[\frac{2 g\left(H-H_{g}\right)(\phi-1)}{\phi\left(\phi+\frac{C_{o}^{2} A_{o}^{2}}{C_{i}^{2} A_{i}^{2}}\right)}\right]^{1 / 2},
$$

where

$$
\phi=\frac{T_{g}}{T_{a}} .
$$

The vent flow rate might not increase with the temperature of the smoke layer. There is a maximum value $m_{\max }$ at a certain smoke layer temperature. The vent flow rate cannot be greater than $m_{\max }$ as $T_{g}$ increases. Value of $m_{\max }$ can be deduced by taking:

$$
\frac{d m_{e}}{d \phi}=0
$$

Differentiating $m_{e}$ with respect to $\phi$ gives:

$$
\begin{aligned}
& \frac{d m_{e}}{d \phi}=\frac{1}{2} C_{0} \rho_{a} A_{o}\left[2 g\left(H-H_{g}\right)\right]^{1 / 2} . \\
& \frac{1}{\left[\phi(\phi-1)\left(\phi+\frac{C_{o}^{2} A_{o}^{2}}{C_{i}^{2} A_{i}^{2}}\right)\right]^{1 / 2}}\left[\frac{-\phi^{2}+2 \phi+\frac{C_{o}^{2} A_{o}^{2}}{C_{i}^{2} A_{i}^{2}}}{\phi\left(\phi+\frac{C_{o}^{2} A_{o}^{2}}{C_{i}^{2} A_{i}^{2}}\right)}\right] .
\end{aligned}
$$

Equating to zero gives:

$$
\phi^{2}-2 \phi-\frac{C_{o}^{2} A_{o}^{2}}{C_{i}^{2} A_{i}^{2}}=0 .
$$

Solving equation (A5) would get:

$$
\phi=1 \pm\left(\frac{C_{o}{ }^{2} A_{o}{ }^{2}}{C_{i}^{2} A_{i}^{2}}+1\right)^{1 / 2} .
$$

As $\phi$ is greater than 1 for $T_{g}>T_{a}, \phi$ is taken as:

$$
\phi=1+\left(\frac{C_{o}^{2} A_{o}{ }^{2}}{C_{i}^{2} A_{i}^{2}}+1\right)^{1 / 2} \text {. }
$$

\section{Appendix B: Derivation of equations (27) and (28)}

From equation (7), the mass flow across the vent $m_{e}$ is:

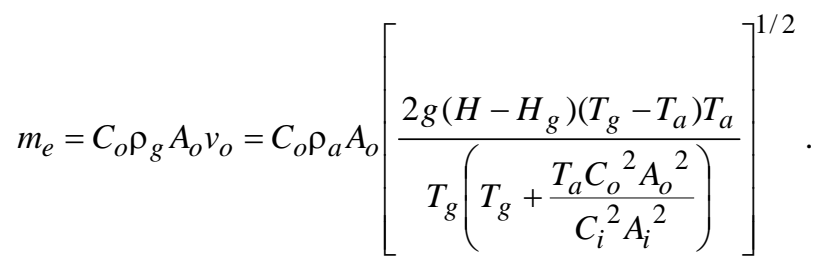


When $A_{i}>>A_{o}, m_{e}$ can be expressed in terms of the smoke layer interface height ratio $\xi$ to the ceiling height $\mathrm{H}$.

$m_{e}=C_{o} A_{o} g\left(2 \rho_{a} H\right)^{1 / 2}\left[(1-\xi) \frac{\rho_{a}}{g}\left(\frac{T_{g}}{T_{a}}-1\right)\right]^{1 / 2}\left(\frac{T_{g}}{T_{a}}\right)^{-1}$

where

$$
\xi=H_{g} / H
$$

Defining

$$
A=C_{o} A_{o} g\left(2 \rho_{a} H\right)^{1 / 2} .
$$

Equation (B1) can be written as:

$$
m_{e}=A\left[(1-\xi) \frac{\rho_{a}}{g}\left(\frac{T_{g}}{T_{a}}-1\right)\right]^{1 / 2}\left(\frac{T_{g}}{T_{a}}\right)^{-1} .
$$

Energy conservation of the hot gas layer would give the smoke layer temperature as:

$$
\frac{T_{g}}{T_{a}}=\frac{Q_{C}}{m_{p} C_{p} T_{a}}+1 .
$$

Using mass conservation to take $m_{p}$ as $m_{e}$, $\xi$ can be calculated by:

$$
\xi=1-\frac{F m_{p}}{A^{2}}\left[1+\frac{m_{p} C_{p} T_{a}}{Q_{C}}\right]^{2},
$$

where $F$ is the buoyancy flux of the hot smoke:

$$
F=\frac{g Q_{C}}{\rho_{a} C_{p} T_{a}} .
$$

Calculating the smoke production rate $m_{p}$ by the axisymmetric plume equation such as that by Heskestad (1984) for a fire at the floor level:

$$
m_{p}=0.071 Q_{C}^{1 / 3} z^{5 / 3}+0.0018 Q_{C}
$$

Putting the above plume equation into equation (B6) gives:

$$
\begin{aligned}
\xi= & 1-\frac{F}{Q_{C} A^{2}}\left[Q_{C}{ }^{2 / 3}\left(0.071 H^{5 / 3} \xi^{5 / 3}+0.0018 Q_{C}{ }^{2 / 3}\right)^{1 / 2}+\right. \\
& \left.\left(0.071 H^{5 / 3} \xi^{5 / 3}+0.0018 Q_{C}^{2 / 3}\right)^{3 / 2} C_{p} T_{a}\right]^{2}
\end{aligned}
$$

As $A_{i}$ might not be larger than $A_{o}$ for some design, putting the plume equation (B9) into equation (B1) would give a general equation on the smoke layer height as:

$$
\begin{aligned}
& \xi=1-\frac{\left(0.071 Q_{C}^{1 / 3} \xi^{5 / 3}+0.0018 Q_{C} H^{-5 / 3}\right)^{2} H^{7 / 3}}{2 g C_{o}^{2} A_{o}^{2} \rho_{a}^{2}} . \\
& {\left[\left(1+\left(0.071 Q_{C}^{-2 / 3} \xi^{5 / 3}+0.0018 H^{-5 / 3}\right) C_{p} T_{a} H^{5 / 3}\right] .\right.} \\
& {\left[\frac{1}{\left(0.071 Q_{C}^{-2 / 3} \xi^{5 / 3}+0.0018 H^{-5 / 3}\right) C_{p} T_{a} H^{5 / 3}}+1+\frac{C_{o}^{2} A_{o}^{2}}{C_{i}^{2} A_{i}^{2}}\right]}
\end{aligned}
$$

\section{STATINIO DŪMU ŠALINIMO ATRIJUOSE ANALITINIS MODELIS}

\section{Ch. L. Chow, J. Li}

\section{S a n trauka}

Tolimuosiuose Rytuose statinès dūmų šalinimo sistemos su natūralios ventiliacijos angomis pradedamos irengti dideliuose prekybos kompleksuose, sandèliuose ir krovinių terminaluose. Tokios sistemos naudojamos ir natūraliai ventiliacijai, ir dūmams šalinti. Šis straipsnis parengtas susirūpinus, kad statinès dūmų išmetimo sistemos yra ne tokios populiarios nei dinaminès dūmų išmetimo sistemos su mechaniniais ventiliatoriais. Autoriai siūlo literatūroje aprašomo paprasto srauto modelio modifikacija, pritaikant ši modelị dūmų sluoksnio sąlyčio su natūralios ventiliacijos angomis aukščiui tirti. Straipsnyje palyginti ir pagristi rezultatai, gauti taikant tiek skaičiuojamosios skysčiu dinamikos, tiek zonavimo modelius kartu su eksperimentiniais tyrimais vietovejje. Pateiktas dūmų šalinimo modelio taikymo pavyzdys didelèje salèje ir padaryta išvada, kad srauto modelis galètų būti taikomas įrengiant natūralią ventiliaciją. Kadangi pagrindinè varomoji jèga šalinant dūmus per natūralias ventiliacijos angas yra dūmų plūdrumas, sistema gali būti veiksminga tik esant didesniems gaisrams.

Reikšminiai žodžiai: dūmų šalinimo sistemos, natūralios ventiliacijos angos, plūdrumas, dūmų sluoksnio sąlyčio aukštis.

Cheuk Lun CHOW just graduated with a PhD degree in 2009 from the Department of Architecture, Wolfson College, University of Cambridge, UK. Her PhD project is on fire hazard of glass buildings and double-skin façades. Her research interests include the application of Computational Fluid Dynamics in simulating fires, natural ventilation, glass façade fires, and fire safety in green buildings.

Junmei LI is an Associate Professor in the College of Architecture and Civil Engineering at Beijing University of Technology. She is a member of China Fire Protection Association and a fellow of Chinese Association of Refrigeration. Her research interests include fire safety in atria, smoke dynamics in tunnels and building energy conservation. 